\title{
Mestre Romão e a cantiga da voz perdida
}

Ruth Silviano Brandão | UFMG

\begin{abstract}
Resumo: A música, como tentativa de não deixar morrer o amor perdido e a voz da mulher amada, no conto "Cantiga de esponsais" de Machado de Assis. Palavras-chave: cantiga, amor, perda.
\end{abstract}

Cantigas sempre habitaram o solo literário e a voz que aí ressoa é antiga como as vozes da poesia oral e contêm a nostalgia de um amor sem fim, uma busca infindável da fusão amorosa. Estou falando de cânticos que falam do amor ou de sua falta, estou me lembrando do Cântico dos cânticos, dos encontros e desencontros do casal nupcial. O Cântico dos cânticos é literalmente um poema de amor, um conjunto de cantos eróticos, provavelmente em função de epitalâmio, da celebração do casal. Um canto nupcial que já fala, entretanto, do desencontro dos pares, dos corpos, dos caminhos, das palavras que marcam as falas da Sulamita e do rei. No seio mesmo das palavras amorosas há a consciência de uma perda passada ou futura, pois a morte, a distância e a separação movem o amor e são seu fim inexorável.

Este é o sofrimento de Mestre Romão de Cantiga de esponsais: cantiga incompleta, cantiga que se recusa terminar, cujas notas estão presas na garganta, na ponta dos dedos que tocam o cravo, nas notas musicais. Não posso 
me esquecer de um livro de Pascal Quignard: Le nom sur le bout de la langue, a palavra na ponta da língua, a palavra sufocada da mãe que ficava muda à sua espera. Em outros trabalhos, o escritor francês fala da voz perdida, do menino que perdeu a voz feminina da mãe e que não pode mais cantar no coro da igreja.

Mestre Romão perdeu a voz feminina de sua mulher e tenta insistentemente recuperá-la. Em outro livro, Pascal Quignard fala de um músico, Sainte-Colombe, e sua melancolia pela perda da mulher amada. Tristeza tão grande que o fez construir a viola da gamba para recuperá-la, cantá-la, colocando-a entre as pernas, abraçando-a para retê-la. Isso acontece no livro e no filme Todas as manhãs do mundo, livro em que a música está nas palavras e no silêncio, pois o silêncio constitui a música.

No conto de Machado de Assis, há também uma igreja onde se faz música, se faz canto, se marca a perda. Mestre Romão era maestro e compositor como Sainte-Colombe, solitário e melancólico como o músico francês, fechado em seu mundo estéril, mudo para o mundo.

Mestre Romão é amargurado pela a música que o abandonou, que o deixou sem inspiração, tal como a mãe de Quignard se sentia quando as palavras lhe fugiam, deixavam-na só, como seu olhar medusino. Olhando a mãe, o filho vai dizer que viu a Medusa: ele teve a experiência da Medusa, da falta, do horror, do real. Mestre Romão sentia que a inspiração não podia sair, assim

como um pássaro que acaba de ser preso e forceja por transpor as paredes da gaiola, abaixo, acima, impaciente, aterrado, assim batia a inspiração de nosso músico, encerrada nele sem poder sair, sem achar uma porta, nada. Algumas notas chegaram a ligar-se; ele escreveu-as; obra de uma folha de papel, não mais. Teimou no dia seguinte, dez dias depois, vinte vezes durante o tempo de casado. Quando a mulher morreu, ele releu essas primeiras notas conjugais, e ficou ainda mais triste, por não ter podido fixar no papel a sensação de felicidade extinta.

A música pode ser uma forma para falar do inconsciente, do inexprimível por palavras, pelo menos as palavras articuladas, encadeadas que também nos encadeiam. A música está em outro registro, menos no dos fonemas ou dos significantes do que uma escrita da letra: a letra sem significante, sem

1. MACHADO DE ASSIS, 1962, p. 388. 
sentido, sem significações, mas fundamental para amarrar o sujeito, não deixá-lo só a céu aberto. De certa forma, a música está fora do tempo ou seu tempo tem outro registro, outra marcação.

Foi ela que sustentou Orfeu, em sua ida ao Hades para buscar Eurídice: música e olhar salvaram e perderam o músico que ousou olhar para trás e ficou cego de luz, cego diante do real da noite. A vida de Mestre Romão transformou-se numa grande noite, noite da melancolia, noite da perda da voz, do timbre, das notas musicais. Tantos anos se passaram e Mestre Romão não saiu de seu Hades e não viu sua amada, como Orfeu que viu Eurídice, mas a perdeu para sempre. Mestre Romão só não a perdeu na lembrança ou numa espécie de reminiscência em que ela lhe aparecia por iluminações, por cintilações. Dessa forma, ele não deixou de olhar para trás, ele se paralisou em sua dor.

Essa experiência do real é indizível, mas é transmissível. De forma deslocada, Mestre Romão falava de sua amada, quando tocava músicas alheias. Nessas horas ele se transportava, ficava absorto diante da orquestra que regia. Mas não era a sua música, não trazia sua amada de volta e ele se calava e entrava mais e mais em seu mundo de muitos sons e de som nenhum, já que a cantiga de esponsais que começara a fazer lhe escapava, fugia de seus dedos.

Fazer a cantiga de esponsais, iniciada em vida da esposa, significava ter sua amada consigo, o que seria seu supremo consolo. Fazer a cantiga seria uma forma de escrita, mas não a escrita das narrativas, não aquela da mimese, da representação e da verossimilhança. Não uma escrita dos sintomas, aquele que se fixa e se repete de forma fantasmática, apontando para as mesmas fantasias do sujeito, ou, falando de outra maneira: uma escrita da cena primitiva, que assombra o sujeito, se ele não consegue escrever de uma outra posição.

A cantiga de esponsais seria escrita de um som perdido, incapturável, mas insistente, pois quem faria epitalâmios no séc. XIX, o século de Mestre Romão? Que tipo de cantiga seria essa perdida no tempo, na aurora de um paraíso neoclássico ou um tempo medieval com suas cantigas trovadorescas? Cantigas de amor para uma dama inatingivel? Ora, os trovadores denunciaram abertamente nas suas canções a incompatibilidade entre amor e casamento, mantendo a dama no alto, em um lugar para além das relações conjugais.

Uma música nostálgica de um tipo de amor desejado, impossível, porque eterniza a relação do par amoroso. Mas insiste. Transmite-se. Talvez como uma carta de amor perdida. Ele não sabia que as cartas de amor se extraviam e podem ser lidas por outrem. 
Mas é preciso falar um pouco mais do desencontro, da dessimetria que há entre os casais. Com outras palavras, Lacan fala que não há relação sexual, pois dois não fazem um: há um descompasso entre os pares amorosos. Fray Luiz de Leon sabia disso, pois afirmou sobre as palavras do Cântico dos cânticos:

E a causa de parecer assim cortadas, é que no ânimo, assenhoreado de alguma veemente paixão, não alcança a língua o coração, nem se pode dizer tanto como se sente, e mesmo isto que se pode não se diz todo, senão em partes e cortadamente, umas vezes ao princípio da razão, e outras o fim sem o princípio; que assim como o que ama sente muito o que diz, assim the parece que, em sendo apontado por ele, está pelos demais entendido; e a paixão com sua força e com incrível presteza arrebata-lhe a língua e coração de um afeto em outro; e daqui com suas razões cortadas e cheias de obscuridade. Parecem também desconcertadas entre si, porque respondem ao movimento que faz a paixão no ânimo daquele que as diz, a qual quem não a sente ou vê, julga-as mal; como julgaria ser coisa de desvario e de desmiolado os meneios dos que dançam, aquele que vendo-os de longe não percebesse o som que seguem, o qual é muito advertir neste Livro e em todos os semelhantes.

Não alcança a língua o coração, diz o Fray, os pares se desencontram, há um corte entre o sentir e o dizer, não se pode dizer tudo o que me atravessa:

não alcança a língua o coração, nem se pode dizer tanto como se sente, e mesmo isto que se pode não se diz todo, senão em partes e cortadamente, umas vezes ao princípio da razão, e outras o fim sem o princípio; que assim como o que ama sente muito o que diz, assim lhe parece que, em sendo apontado por ele, está pelos demais entendido; e a paixão com sua força e com incrível presteza arrebata-lhe a língua e coração de um afeto em outro; e daqui com suas razões cortadas e cheias de obscuridade.

As palavras de amor são cortadas, não se escrevem como desejam os pares. Entre o que sentia e o que tentava dizer, havia um corte e Mestre Romão não sabia. E essa linguagem era de outra ordem, não se articulava como as das

2. LEON, 1944, p. 28.

3. LEON, 1944, p. 28. 
pessoas que falam em prosa, com lógica e concatenação. No entanto, essas palavras faltantes existiam fora de sua boca, longe da ponta de seus dedos que buscavam seu cravo, na ponta da língua, no ponto de mesmo de se realizarem. Tornam-se palavras começantes.

E se realizam, mas em outro lugar, longe, no campo do Outro, no momento fugidio e incapturável do encontro amoroso, lá...lá nos olhos dos amantes, lá, lá. Com melhores palavras que as da psicanálise, Machado de Assis fala da impossibilidade da relação sexual. Da relação, do laço, da coincidência, da simetria. É dessa impossibilidade que a cultura ocidental não quer saber, pois prefere a ilusão, a busca, a esperança do amor, este dom máximo: é o que a cultura nos transmite, deixando-nos em suspensão.

O conto termina com a música desejada pelo velho maestro, mas não cantada por ele, não composta por ele:

Lá, dó...lá, mi...lá, si, dó, ré...ré...ré,,, Impossível! nenhuma inspiração. Não exigia uma peça profundamente original, mas enfim alguma coisa que não fosse de outro e se ligasse ao pensamento começado. Voltava ao princípio, repetia as notas, buscava reaver um retalho da sensação extinta, lembrava-se da mulher, dos primeiros tempos. Para completar a ilusão, deitava os olhos pela janela para o lado dos casadinhos. Estes continuavam ali, com as mãos presas e os braços passados nos ombros um do outro; a diferença é que se miravam agora, em vez de olhar para baixo. Mestre Romão, ofegante da moléstia e de impaciência, tornava ao cravo; mas a vista do casal não lhe suprira a inspiração, e as notas seguintes não soavam.

- Lá...lá...lá...

Desesperado deixou o cravo, pegou do papel escrito e rasgou-o. Nesse momento, a moça embebida no olhar do marido, começou a cantarolar à toa, inconscientemente, uma cousa nunca antes cantada nem sabida, na qual cousa um certo lá trazia após si uma linda frase musical, justamente a que mestre Romão procurara durante anos sem achar nunca. O mestre ouviu-a com tristeza, abanou a cabeça, é à noite expirou.

Vemos que da música iniciada restam notas que podem ser notações musicais, mas evocam um lamento, resíduos de murmúrios, ambíguos por sua

4. MACHADO DE ASSIS, 1962, p. 389-390. 
posição no texto, mas significantes: si e mi e seu apontar para um íntimo; dó representante de uma dor prolongada, sem palavras, ré de uma falta, lá, lá... inatingível, indizível. Entretanto, dó, ou ré ou mi são notações musicais que, isoladamente, representam sons que nada significam isoladamente. São restos sem significação, apenas sons isolados que não compõem uma música. Alguma coisa foi erodida das palavras iniciais, caíram os ornamentos de uma composição musical, caíram os semblantes.

Mestre Romão transmite a falta, como outras personagens de Machado de Assis, com a Maria Regina do Trio em lá menor, que busca o que não há, nem nas estrelinhas gêmeas do céu. O desejo do encontro que a música propiciaria está lá, lá, inatingivel, aquém da linguagem ou da escrita domesticada pelo senso-comum.

Entretanto, dessa falta nasce a criação: se houvesse o Um amoroso não se falava dele, viver-se-ia indefinidamente um gozo que acabaria por ser mortífero. A música de Orfeu é uma escrita. Orfeu somos todos nós que passamos, de uma forma ou de outra, pela experiência do amor e da solidão. Solidão diferente daquela em que o solitário se aconchega, pois o estar só lhe é agradável, é uma opção - estar só comigo, na minha alma-casa. É uma coisa que são dois: eu e eu. Um espelho acolhedor, mas mortífero, onde também, na minha loucura, quero prender o outro, este que amo de um amor capturante.

Outra forma de solidão é estar só, partido ao meio sem meu amor, aquele que coroei de ouro, a quem dei minha vida, minha música, minha voz, depois do tempo jubiloso em que vivemos em dois. E agora só há um. Um só. Um sozinho no seu desamparo. Imaginar Orfeu nessa hora: sem voz, sem olho para olhar. Menos duro do que se não tivesse tido Eurídice por tão pouco tempo, ela sua amada, aquela com quem viveu as núpcias. A dois. Agora é menos um. Orfeu é menos um.

Há uma outra lógica aí: y a de l'Un. Tentar imaginar Orfeu só um. E, num mínimo segundo, por um átimo, cego. Neste momento, Orfeu ainda não sabe que não perdeu a voz, pois sua perda foi tão radical, que não há palavras para dizer. Dizer esta solidão de tirar a voz, que me põe cego. Entre a voz e o olhar, parece que tudo está junto para conspirar contra mim mesmo, para a minha desgraça.

Mas desse lugar se escreve: algo escreve.

Marcel Detienne escreveu, dentre outros, um livro sobre a escrita, $A$ escrita de Orfeu e revela como a escrita estaria ligada a Orfeu. Antes dos livros, antes da linguagem escrita, entretanto, já havia a escrita da música, da voz e dos 
sons e era esse tipo de escrita que Mestre Romão buscou: a escrita da origem do amor, mesmo que fosse de um amor efêmero como o seu, que durou tão pouco, como o de Orfeu por Eurídice. São os amores efêmeros que fazem poesia, pois não envelhecem, não entram na esfera do quotidiano e por isso parecem sagrados.

Se Romão não conseguiu fazer sua cantiga esponsalícia é porque ela está no campo do Outro, da cultura, como um lamento e uma ode à alegria. Uma nostalgia do Um, aquele impossível do 1+1=1.

Quanto à escrita da música, ela não se reduz à escrita das notas, de sua notação, mas o que a música deseja é uma inscrição, gravada na memória, inscrição de uma lacuna que fez uma marca. A lacuna foi deixada pela esposa amada, morta, todas as amadas se encontrando em Eurídice, sintetizando-se nela, esta mulher que o amador não deixa morrer e cuja não-morte causa melancolia e uma escrita melancólica, do melancólico, aquele que não suporta a perda, aquele que não completa o luto, aquele que cultiva sua ferida, de cujo centro escorre um sangue que não se estanca, sintomaticamente.

É comum falar-se de frase, mesmo relativamente a uma música sem vozes humanas, se isto é possível. As vozes estão lá, ressoando, em queda, pois as vozes caem como objetos sonoros. Quem as escuta? Ao fazer a música para a amada, quem a escutará? Podemos recorrer a Roland Barthes, quando fala numa terceira forma de escuta:

A terceira escuta, enfim, cuja abordagem é moderna (o que não quer dizer que seja superior às duas outras), não visa - ou não espera _ signos determinados, classificados; não aquilo que é dito, ou emitido, mas aquele que emite: deve ser desenvolvida em um espaço intersubjetivo, em que "escuto" na verdade quer dizer "escuta-me", a escuta apoderase, pois, para transformá-la e lançá-la cem cessar no jogo da transferência, de uma "significância" geral, que já não é concebível sem a intervenção do inconsciente.

Barthes fala do obtuso, de um sentido que não é o simbólico, não é intencional, é "demais", a mais, sentido que se "apresenta como um suplemento que minha intelecção não consegue absorver bem, simultaneamente teimoso e fugidio, eu proponho chamá-lo o sentido obtuso".

5. BARTHES, 1990, p. 217. 
Tentamos falar dessa escrita presente na obra de Machado de Assis, quando os fatos são poucos, a narrativa, escassa, mas a força da letra não deixa de produzir textos, lugar onde a criação se faz, infinitamente, nem sempre no campo da representação, nem do senso-comum. Na letra, ao pé da letra.

Résumé: La musique en tant que effort de ne pas laissez mourir l'amour perdu et la voix de la femme aimée, dans "Cantiga de esponsais", de Machado de Assis.

Mots-clés: chanson, amour, perte.

$$
\text { Referências }
$$

BARTHES, Roland. O óbvio e o obtuso. Ensaios críticos III. Trad. Lea Novaes. Rio de Janeiro: Nova Fronteira, 1990.

LEON, Luis de (Fray). Obras completas castellanas. Edición revisada y anotada por Félix Garcia. Madrid: Biblioteca de Autores Cristianos, 1944.

QUIGNARD, Pascal. Tous les matins du monde. Paris: Gallimard, 1991. Le nom sur le bout de la langue. Paris: Gallimard, Folio, 1993.

MACHADO DE ASSIS, Joaquim Maria. Histórias sem data. In: Obra completa.

v. II. Rio de Janeiro: Aguilar, 1962. 